トラ全体のバランスを取っている.

$M_{2,3}$ は，ホール全体の響きを収音するととむに，ス テレオ拡がり感をとることを目的としたマイクで, エコ ーマイクと呼ばれで扬り, 通常マイク間隔は約 $10 \mathrm{~m}$, 無指向性にしている.

全体的な音色設定は， $M_{1}$ と $M_{2,3}$ の調和により決定 されるが, 楽器間の部分的なバランス補正用に $M_{4 \sim 9}$ が 補助マイクとして使用されている.

補助マイクの使用にあたっては, メインマイクの定位 と補助マイクの定位をあわせて使用するとともに, 補助 マイクの過度の使用は, 特定楽器のクローズアップをま ねくことになるので，エコー装置の併用によるなど，全 体の音色形成に充分留意する必要がある.

\section{7.むす び}

ワンポイント収音における概略を述べたが，頁数の限 定むあり，アウトラインにならざるをえなかった．詳細 については，下記の文献3) 5)を参照していただきたい。

(昭和 54 年 12 月 12 日受付)

\section{〔参考 文 献〕}

1) J. Zwislocki: Just noticeable difference in dichotic phase, JASA, 28 (1956) 860

2) A.W. Mills: Lateralization of high-frquency tone, JASA, 32 (1960) 132

3）青柳一雄監修：放送ミクシング（スタジオ編・局外中継 編), 兼六館

4) 高橋良, 藤田尚：FM ステレオ放送技術，日本放送出版 協会

5) 浅見啓明：ステレオミクシング，放送技術, 19, 9(1966); 21, $4 / 5 / 6$ (1968)

\title{
3-3-2ママルチポイントマイクによる音楽番組の制作
}

\section{1. ま がき}

ワンポイントマイクによる収音でオーケストラを録音 する場合, ソロ演奏や弦楽四重奏と違いマイク位置の決 定が大変難かしく, 音楽的なバランスをとるのに補助マ イクを使用することが多い. しかしての場合, メインマ イクと補助マイクとの間で音源との距離が違うため, 遠 近感が逆になる事態が生じうる，乙れを改善するため に，各楽器のパートごとにマイクを配置するようにな る.とうして現在ではほとんどのミキシングがマルチポ イントマイクによる収音で行われている。

そてで「サウンドイン“S”」のステレオ収録を例に して，マルチポイントマイクによる番組制作の実際を紹 介してみたいと思う.

TBS のスタジオ音楽番組「サウンドイン“S”」(写真 1) は，外国のショウに追いつけ追い越せをキャッチフ レーズに 6 年前誕生したユニークなショウ番組で, 骨子 は歌とダンスがメインになっているが，番組の中にスピ ード感やショウの盛り上りを図るため, テレビ機構をフ ルに駆使し，映像，音声，照明，美術，衣裳とあらゆる 分野にわたってウェイトを戈くととむに，プログラム全 体に各セクションの個性を充分に発揮できるよう配慮が

"3-3-2 A Method of Technique Musical Program for TV Broadcasting; by Using Multiple Microphones" by Hideo Wada (Department of TV Production Engineering, Tokyo Broadcasting System Inc., Tokyo)

\section{株式会社東京放送和田英雄}

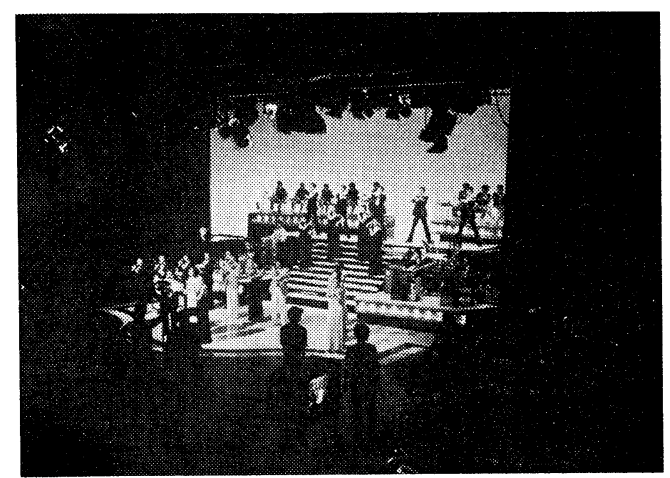

写真 1 「サウンドイン “S”」VTR 集録風景

なされている。特に 1978 年 11 月からのステレオ放送開 始以来, 企画・構成面でのステレオ効果の研究や, 画像 との相乗作用によるステレオ効果の拡大を図る等の創 意, 工夫がなされている.

一方，音声面でも番組制作に対応したシステムとし て，テープロックシステム (以下 TLS) 装備の $16 \mathrm{ch}$ マルチ録音機 (STUDER 社 A-800, 以下 $16 \mathrm{ch} \mathrm{ATR)}$ とミニコンピューター (以下 CPU) 制御のコンソール (NEVE 社 8088, NECAM 6 ) との組合せによるループ オペレーションシステム1)を採用し, 現在 TBS “G 夕多重サブ”に扔いて運用され, 省力化と品質の向上は 各界から洼目を集めている。 


\section{2. マルチポイントマイク収音について}

マルチポイントマイクによる収音の利点として,

(1) 楽器音の明瞭度が良い

(2) 音像定位をはっきりさせ方向性を明確にすること ができる

(3) 楽器間の音量バランスの違いに対し, 弱音楽器の 音量を上げるととにより音楽上のバランスが容易に できる

(4) マイクを楽器に対してオンマイクにセッティング できるため， $S / N$ が良くなり，PAのハウリングマ ージンが向上する

(5) オンマイクによる近接効果を利用した音色形成を 可能にできる

等があげられるが, 反面, オンマイクセッティングのた め音源からの直接音だけとなり，やせた音になる。ま た, 多数のマイクが必要となり, マイク相互間の音の干 渉，かぶりが多くなるので，エコーやイコライザーでの 補正が必要である.

\section{3. 録音スタジオでの事前録音}

当番組の一部には，音楽を事前に録音して，VTR 収 録時にその録音テープを再生してスタジオ収録を行うブ ロックがあり，すなわちカラオケ作成を行う必要がある ため，マルチ録音による音楽録音を先行して行う.
まず，フルバンドとキーボード類が録音され，タイム チャートが作られ，次にストリングス群およびパーカッ ション等がダビングされてマルチトラックテープの素材 が完成する. 後日，その素材にェコー，イコライザー, ディレイマシン, フェーズシフター等のエフェクト付加 をし， $2 \mathrm{ch}$ ステレオとして $6 \mathrm{~mm}$ 幅テープにミックス ダウンする，それを再度， $16 \mathrm{ch}$ テープにダイレクトダ ビングを行い，カラオケマザーテープが完成する.

次に，完成されたカラオケテープにコーラスをダビン グする. 通常一組のコーラスグループに対し 2 トラック を使用しているが，時にはむう一度オーバーダビングを 行い，画像に合わせた音像定位を与えるようにしておく 場合もある。

録音部分の他に “スケッチ”と称し生音部分の音合せ む行われ，譜面チェックやタイミングの修正を行い，唄 および踊りのリハーサル用として，6 $\mathrm{mm}$ またはカセッ トテープに録音している.

\section{4. マイクセッティング}

テレビに括けるバンド配置は，画像との関係で，録音 スタジオでの配置のように分離した形にできることが少 ない．僅かにアクリル板で囲っての遮音程度であり，乙 れも照明効果を損うとのことで使用できない状態が多 い. 図 1 に当番組のバンド配置とマイクセッティングを 示す。罒のように，ブラス・サックス台はレール上を左

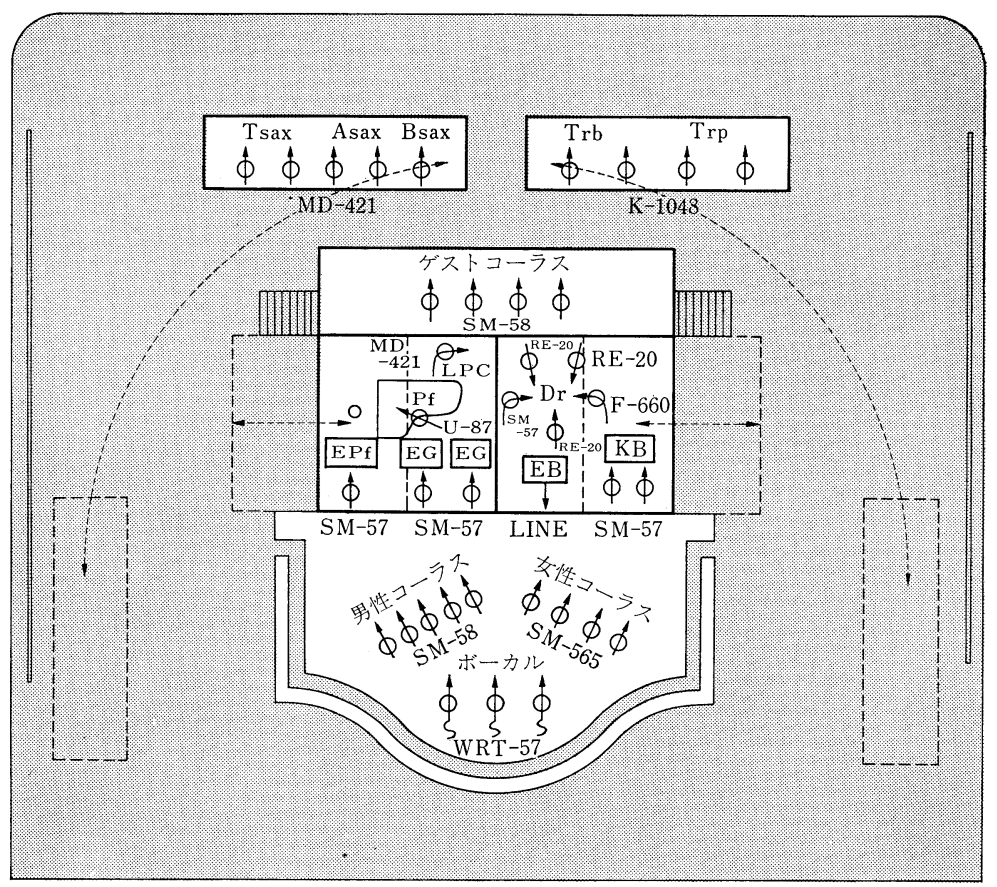

図 1 「サウンドイン“S”」のバンド配置とマイクアレンジ 


\section{3. ステレオ制作技術}

右半円形に，また，前面にある 2 つのリズム台むおのお の左右に移動できるようになっていて，演奏中各バンド 台を移動させ画面効果を上げている，ケーブルに関して は，10 芯マルチケーブルを 5 ～6本使用し，ボックス または先バラによりマイクに接続している.

マイクロホンに関しては，サックスセクションに指向 性の狭い MD-421 1 本ずつ配し音のかぶりを防ぐと ともに，フルートの持ち替えによるマイクポジションの 変更を演奏者自身で行うことを容易にしている．ブラス セクションにはコンデンサー型の K-1048 を 2 演奏者に 対し 1 本のマイクを使用して，響きのある重厚な迫力あ る音に収音している。ピアノの音は直接音を重点に収音 し，歯切れの良いクリアーな音を目的とし，高中音域を 中心に $f$ 特の良い $U-87$ を使用し，できるだけダンピ ングの良い音にしている.

しかし，ロックバンド等の電気楽器が多い中での収音 には，音のかぶりを防ぐため，ダイナミックマイクの使 用むある。エレキギターやキーボード群に関しては，い ろいろなアタッチメントを使用しての演奏が多いため, スピーカー出力音をマイクによって収音する場合が多 く，音圧が高いことむ考えダイナミックマイクを使用し ている，エレキベースは，クリアーな音色を求める意味 で直接 line 出力から収音している，ドラムスの収音で は，最近のリズムの傾向として，アタック音の利いたク リアーな音を要求されていてマイク本数む多くなり，特 に瞬間的な音圧が大きく，オンマイクによる収音をする ため，ダイナミックマイクの使用が多い.

\section{5. チャンネルプラン}

レコード会社に扔いては，マルチチャンネル録音方式 により各楽器が分割採音され，チャンネルトラック間の “ピンポン”や“パンチイン”などの事前ミックスや重 複録音の方法により，チャンネルトラックの節約がなさ れているが, テレビの場合, 画像との関係で多数の楽器 によるリアルタイム進行での同時演奏を1〜15トラック (16 番目のトラックはVTR との同期信号である SMP$\mathrm{TE}$ タイムコードが録音される）に收録しなければなら

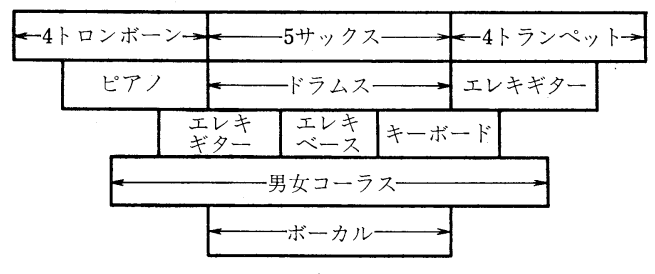

L 側スピーカ 中央 $\mathrm{R}$ 側スピーカ

図 2 「サウンドイン“S”」のサウンドステージ例
ない. NEVE コンソールには, チャンネルルーチング にパンポットを持っていて，2 チャンネル間で数種の楽 器を前むって $L \sim R$ 間に音像定位の振り分けができる ので，サックス，ドラムスなどはプリミックスして各ト ラックに収めているが，後のミックスダウンでのエコー 付加，音の補正，音像定位を考慮して，事前に充分なプ ランニングを立てる必要がある.

\section{6. サウンドステージ (図 2)}

基本的には正面画像での楽器配置通りのサウンドステ ージを構成しているが，音楽的な調和やステレオ効果を 考え，そのつど音像定位を変え，安定した方向感を与え ている。

バンド関係では，コンパチブルステレオでの両立性を 考え，エレキベース，メロディー楽器はセンター定位と し，ドラムスはボーカルの邪魔にならないようセンター 中心に拡げている，ブラス，サックスは $L \sim R$ 間に平 均に拡げ，音楽的な意味で重量感を与えている。コーラ スは，ボーカルやコーラスどうしの掛合いなどの場合， 片側任定位させることがあるが，一般的には $L \sim R$ 間 に拡げている，しかし，あまり拡げすぎると各パートの 音がばらばらに聴えるので，そのときは音像幅を狭める 必要がある。

ボーカルはセンター位置が基本になるが，出演者が複 数の場合や音楽面でのステレオ効果之演出上の位置的表 現効果などにより $L \sim R$ 間に拡げるととや，定位の移 動む, 今後, 画像との相乗作用に上り, ステレオ番組の 実践として効果を拡大させて行くと思われる。

オンマイク収音によるマイク分岐方式のステレオ再生 の場合，どうしても音の方向感ばかりを重視しがちで， サウンドステージ上，横への拡がり感だけとなり，奥行 のない音になることが多い，今後の課題として，音楽自 身が持っている融合された音色効果やバランス感と，空 間的な音の分布の拡がり感などの自然な定位感や音声上 の明膫さを得るよう，ステレオミキシングの基本を守 り，内容を密にしたプログラムをいかに表現してゆく か，可能性を求めなければならない。

\section{7.ミキシング}

当番組の使用マイク本数は約 40 本位となる. そてで 今回, 運用面での即応した音声卓として，NEVE 社製 NECAM 新コンソール (40 入力, 16/4 出力) を 1979 年 12 月より導入し，運用している. コンソールの機 能として，まず入力に扔いてチャンネルルーチングで

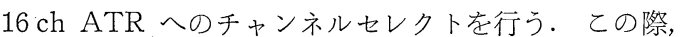

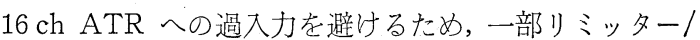


コンプレッサー(NEVE 33609型, SCAMP SOI 1) を使 用し，各チャンネル入力は録音機の最む適性なレベルで 録音し，ミックスダウン時の $S / N$, ひずみ率を良くす るようにする。 また，イコライザーに関しては，ミック スダウン時のテープヒス改善のため, できる限り収録時 に加土している. 一方, 各チャンネル入力はモニター系 に送られ，エコー付加とパンポットによる音像定位を与 えられてのモニターミキシングを行い，収録 VTR に録 音される.

\section{VTR 収録}

$16 \mathrm{ch} \mathrm{ATR} \mathrm{の} 16$ 番トラック (コードチャンネル) と1インチ VTR (SONY BVH-1000)の ch 3 には同 一の SMPTE タイムコードを収録し，テープロックと VTR 編集時のアドレスとして使用している.（図3）

VTR 収録後, VTR プレビューを行うが，同時に 16 ch ATR に録音された 16 ch テープの再生チェックを, TLS によりテープロック状態で，音およびロックのチ エックも行っている.

\section{VTR インサート収録}

前項の要領にて収録された VTR を再生し，一部，映 像，音声の重衫どりを行い，もう1台の VTR に収録す る工程である。（図 4 )

音声関しては, 再生 VTR と $16 \mathrm{ch} \mathrm{ATR} \mathrm{をテー}$ プロックさせて，再生トラックの音をシンク再生*し， 空トラックに音の一部が録音され，両方の音をミックス

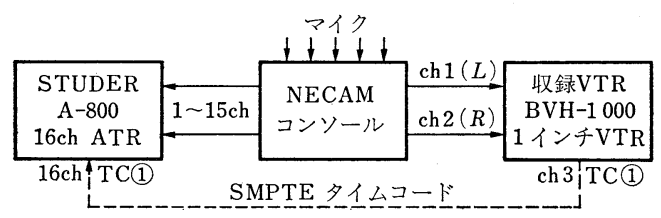

図 3 VTR 収録系統図

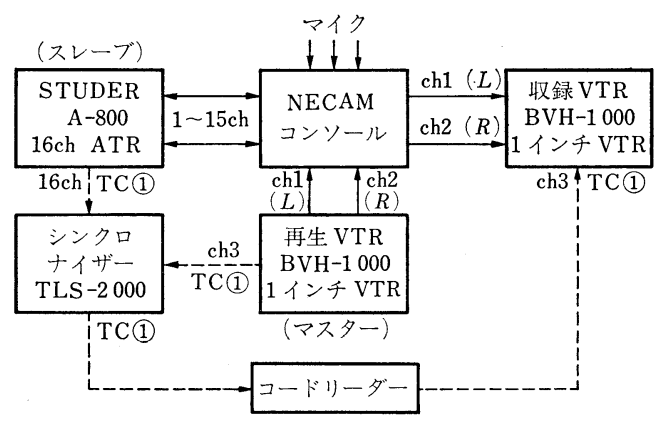

図 4 VTR インサート収録系統図

* マルチ録音では事前録音された音を録音へッドで再生し，その音を聞 きながら次の音を他のトラックに録音する。

308 (44)
して収録 VTR に収録する。また，収録 VTR の ch 3 には再生 VTR とテープロックに使用されたタイムコー ドをコードリーダーにより波形整形して収録しておく

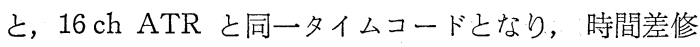
正 (OFS) することなく，VTR インサートを何度む連 続して行うことができる.

\section{VTR 編集 ${ }^{2)}$}

VTR 収録された画像は，タイムコードをアドレスと して電子編集装置により1フレーム単位の編集を行って いる. その際, 素材テープのオリジナルタイムコード と，編集時新しく連続したタイムコードに入替えられた 完成テープ双方の編集点のタイムコードをプリントアウ トして, ミックスダウン時の OFS のデータとして使用 する。なお，編集された放送用完成テープから $3 / 4$ イン チビデオテープにタイムコードをスーパーしてダビング し，ミックスダウンのリハーサル用としている.（図 5)

\section{0. ミックスダウン}

3/4 インチ VTR (BVU-200) 抢よび1インチ VTR

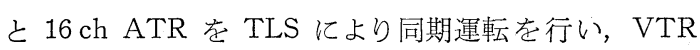
編集により画像の完成された放送用マザーVTR テープ 亿完成した音声を入替える作業である（図6).

NECAM のシステムは，サーボ機構を持つフェーダ 一の操作をコンピューター (CPU) 亿記憶させ, 再現す るととができる.フェーダーのッマミにはタッチセンサ

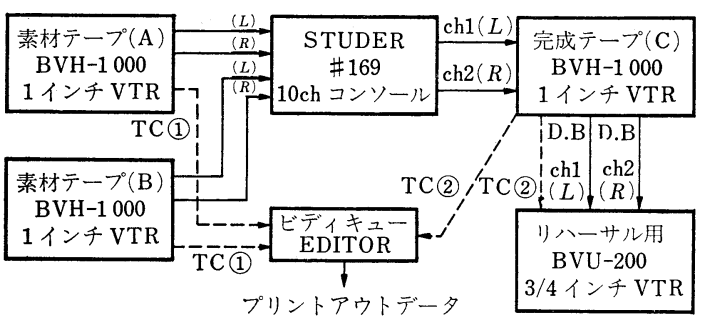

図 5 VTR 編集概略図

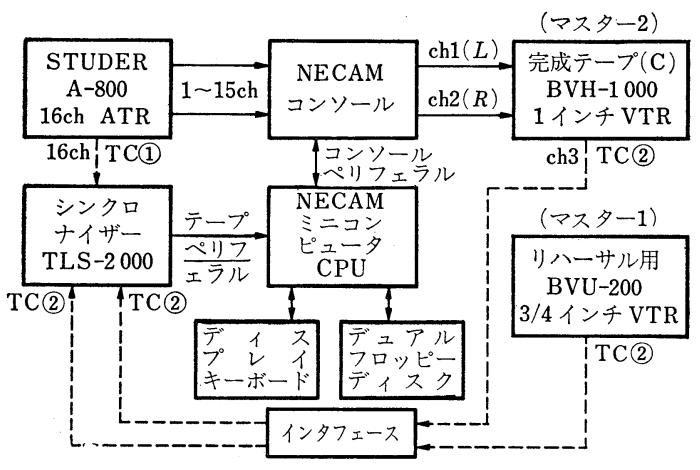

図 6 ミックスダウン系統図 
一が仕込まれていて，ッマミに指を触れるだけでフロッ ピーディスクに書込み，書替えができ，何度でむミキシ ングの修正を行うことができる. 使用例として,

（1）まずバンド関係の音量バランスをミキシングし “MIX 1 ”として記憶させ，次に ”MIX 1 ”再現させ ながら，唄およびコーラスの音量バランスを仕上げ “MIX 2”を記憶させるというように，何回も組立て修 正して1曲ができ上る.

（2） 1 曲をいくつか代分割してミキシングする．乙 の場合, 一連の “LABEL” 番号により曲の途中個所(例 えば譜面の練習番号) を指定し，何ブロックかに分けて ミキシングを完成させ，その分割した“MIX”をコンピ ユーターの “MARGE”機能により, フロッピーディス ク上で編集，組立てを行い，曲の初めから終りまでの新 しい“MIX”としてフェーダー上に 1 曲の連続した完成 ミキシングとして再現することができる.

そのほか, グループの機能として，1つのフェーダー を上下するととにより，任意のフェーダーをリンクした 状態でのグループを複数組むととができ, 複雑な音量バ ランスのミキシングを行うととむできる.

TLS-2000 の機能としては, 16 ch ATR (スレーブ) の 20 アドレスの記憶ができるオートロケーターはむと より,タイムコードを使用してのアドレスはフレーム単 位でできるので正確である，また，マスターコントロー ル操作により，VTR（マスター）の音声トラックへ“パ ンチイン”“パンチアウト”のぼかに, 再生, 早送り, 巻戻しの自動化が可能である. また, TLS-2000は SMPTE タイムコードのみならず, テープトランスポート
のタイミングインディケーターパルスとも同期させるて とができるので, VTR 側のタイムコードの一部が脱落 して連続していなくとも，同期を失うことなく運転が可 能である.さらに，サウンドエフェクト (SE) 用テープ 再生機を，4台までアドレススタートさせることができ る大変融通性のあるシステムであり, 今後, レベルアッ プされた密度の高いステレオ番組の提供が行えると思 う.

\section{1.むす び}

以上，マイク収音から VTR-TLS-NECAM の組合せ によるループオペレーションシステムを, 番組制作面か ら簡単に紹介したが, 詳細については，3-1 章を参照願 えると幸いである。

今後, テレビステレオ放送の諸問題の解決を願い, 新 技術の開発と発展のため多くの試行を重㱛, 番組制作面 での機能を充分生かすべく現場努力を続けるととむに， ミキシング技術面であいっそうの努力が必要であると考 える.

終りに，ご助言をいただいた関係各位に樑く謝意を表 します。

(昭和 54 年 12 月 18 日受付)

〔参考 文 献〕

1）加藤：SMPTE タイムコードを使ったテレビ音声処理の 新システム，放送技術，32，11(1979） 89

2）加藤, 和田, 椎木, 领塚：テレビジョン音声多重放送の ステレオ番組制作とその設備，テレビ学会放送現業技術 研資，PBE 12-2 (1979.3) 5

\section{3-3-3＼cjkstart野球中継におけるステレオ番組}

\section{1. ま がき}

テレビに打けるステレオ放送は，まず音楽番組であ り，スポーツ番組，ショー番組などと続いている．今後 は, ドラマのステレオ番組む開始されるであろう，スポ ーツ番組のステレオ化は，とくに屋外スポーツに扔いて 臨場感のある番組として考えられる.

そとで，スポーツ番組のステレオ放送の実例として， テレビ朝日における野球中継を取りあげ，その実際の収

"3-3-3 Stereophonic Program in Out Side Broadcasting of Baseball Game" by Masakazu Shiraishi (TV Asahi Audio Engineering Section, Tokyo)

第 34 巻 第 4 号 (1980)
株式会社テレビ朝日白石雅一

音方法やマイクアレンジ, そして音像定位, 画面と音声 の関係，また収音時の問題点などについて述べる.

\section{2. スポーツ中継のステレオ化}

音楽については，以前から FM 放送やレコードにより なじみが深く，すでに制作技法，ミクシング技法などが 定着している.

スポーツ番組は，自然の音を中心として制作されるむ のであり, そのステレオ音響は, 臨場感にあふれた新し い素材として提供できるむのと考えられる. しかし, 制 作する側としては，大変にむずかしい問題が存在してい る.すなわち，視聴者はどての席に位置すればよいのか

(45) 309 